\title{
Teacher Leadership Model: Roles and Values
}

\author{
Wan Suhaila Wan Yaacob ${ }^{1}$, Dr Yahya Don ${ }^{2}$ \\ ${ }^{1}$ Universiti Utara Malaysia, 06010 UUM Sintok, Kedah, Malaysia \\ wsuhaila@gmail.com \\ ${ }^{2}$ Associate Professor, Universiti Utara Malaysia, 06010 UUM Sintok, Kedah, Malaysia \\ d.yahya@uum.edu.my
}

\begin{abstract}
This project paper aimed at identifying the dimensions for teacher leadership model. The instrument used to measure the dimensions was adapted from Teacher Leadership Self-Assessment (TLSA) by Katzenmeyer and Moller (2009). This measurement tool consists of 47 items distributed into seven dimensions namely 1) selfawareness, 2) leading change, 3) communication, 4) diversity, 5) instructional proficiency and leadership, 6) continuous improvement, and 7) self-organization. This project paper involved 130 teachers of Mara Junior Science Colleges in the state of Kelantan, Malaysia. Structural Equation Modelling technique was utilized to perform the required statistical analysis of the survey data. Exploratory Factor Analysis (EFA) and Confirmatory Factor Analysis (CFA) were carried out to substantiate the dimensions used. Based on the EFA and CFA, 4 dimensions are relevant for teacher leadership practice in Malaysian setting with 28 items identified to have high value of validity and reliability. The four dimensions are labelled as 1) self-awareness, 2) communication and change, 3) diversity and instructional proficiency, and 4) organized and continuous improvement. These dimensions could be characterized as values and roles of teacher leaders.
\end{abstract}

Keywords: Teacher Leadership, Roles, Values

Academic Discipline / Sub Discipline: Education, Leadership

Subject Classification: Education

Analytical Method: Survey

Type: Literary Analysis

Language: English

Date of Submission: 2018-01-20

Date of Acceptance: 2018-02-20

Date of Publication: 2018-03-15

ISSN: 2321-1091

Volume: 12 Issue: 01

Journal: Journal of Social Science Research

Publisher: CIRWORLD

Website: https://cirworld.com

This work is licensed under a Creative Commons Attribution 4.0 International License. 


\section{Introduction}

Leadership is about influencing relationship. In a relationship between a leader and followers, the aforesaid functions as an inspirational figure that inspires others to produce greater efforts (Henman, 2017). It is an influencing process whereby the so-called leaders would be exerting power in order to control the situation so as to result in the desired goals or objectives of an organization. Theories of leadership emerge and experience evolution starting from Theory $\mathrm{X}$ and Theory $\mathrm{Y}$ which encompass the style, behaviour and situation of leaders to contingency theories which denote the task-oriented leaders or relationship-oriented leaders (Henman, 2017). The 'new' leadership theory has identified the dissemination of leadership or also known as distributed leadership theory which has become the origin of the teacher leadership (Wills, 2015). Distributed leadership theory states that organisation can perform with the absence of leaders because Gronn (2000) believes leadership is being distributed among the agents in the organisation. In an educational institution, the agents would be the teachers and these teachers portray leadership competencies. Leadership among the teachers is evidence in terms of authority, values, interests and personalities. Leadership values being distributed among the teachers will produce teachers who act as leaders in their classrooms and manage to influence the students and colleagues for better performance (Muijs and Harris, 2003).

Hence, there is a significant contribution of teacher leadership to the performance of the teachers by the positive influence it has upon students and other teachers. Teacher leaders play an important role in making the difference in student performance as well as teacher performance (Wills, 2015; Berry, Daughtrey \& Wieder, 2010; Sugg, 2013). Having the values of teacher leaders in each teacher is a must for teachers to commit to their responsibility as educators. These values will determine the roles that teachers will play in the classroom and beyond in order to produce positive impact on the students and their performance likewise. Several studies have outlined the values, roles and significance of the teacher leadership to prove how they affect teacher performance.

Reformation in leadership style is a must so as to ensure that changes happen from bureaucratic leadership to distributed leadership (Kementerian Pendidikan Malaysia, 2011) making empowering teachers as leaders a reality (Terry, 2017). Only with teachers acting as leaders in their classrooms that teacher performance will improve and thus has a positive influence on student performance.

\section{Concept and Definition of Teacher Leadership}

York-Barr and Duke (2004) defines teacher leadership as individual empowerment of the teachers and bringing management to the teachers' level. It is reported by Berry, Daughtrey and Wieder (2010) that teachers who are granted with more authority over the school policies and exceeding degree of autonomy in their career are more prone to stay in teaching profession. This stresses on the importance of the teachers being the core functions in the realm of teaching and learning. They conclude that teacher leadership is leading the way to effective teaching; which is an exceptional teacher performance. Terry (2017) believes that the concept of teacher leadership stems from the idea of empowering teachers as leaders. He defines teacher leadership as a paradigm shift in leadership whereby significant decisions regarding teaching and learning are made by the figures who are working most closely with the students instead of anyone who is at the top of the hierarchy and they are definitely the teachers.

Not being left behind, Katzenmeyer and Moller (2009) being the champion of teacher leadership, define teacher leaders as "leaders within and outside the classroom; identify with and contribute to a community of teacher learners and leaders; influence others to improve their teaching practice; and accept responsibility for realizing the goals of their leadership."

Norashikin Abu Bakar, Ramli Basri and Foo Say Fooi (2015) in their research, the Relationship between Teacher Leadership and Students' Academic Achievement, describe teacher leadership as leadership contributes by all teachers by means of teachers are all set for lifelong learning, developing the ability of teachers and willing to accept greater leadership qualities. Wills (2015) accentuates teacher leadership as the practice of leadership in three main domains namely excellence in teaching, collaboration with colleagues and participation in decision- 
making. She concludes that a teacher leader is "an excellent educator who collaborates with her colleagues to improve teaching and participates in the school wide decision-making process." Villiers and Pretorius (2012) have concluded teacher leadership is in existence in the Eden and Central Karoo Education District of the Western Cape Province in South Africa due to the fact that effective teacher leadership is the key aspect in achieving school improvement. Suffice to say that teacher leadership is indeed an important element in an educational institution should the teacher performance be the indicator for the school achievement.

\section{Roles and Values of Teacher Leadership}

Some perceive teacher leadership based on three roles that teacher leaders play namely leadership of students or other teachers, leadership of operational tasks and finally leadership through decision-making or partnership (Katzenmeyer \& Moller, 2001). The first role usually refers to the teacher leadership performance as facilitator or coach when working with the students and mentor or trainer when undergoing courses for teacher development. The second role, leadership of operational tasks, is the role when teacher leaders are keeping the school organized and implementing activities or programmes in order to achieve the school's goals. They can be the heads of departments, committees of any task force or action researchers. The final role, leadership through decision-making or partnership, is when teachers are making decisions based on their positions such as committee members of school improvement teams (Muijs \& Harris, 2003).

Mulford (2003) has stated multiple conceptions of the teacher's role such as team leader, lead teacher, teacher researcher and master teacher. Exercising these roles is indirectly expressing the teacher leadership in the teachers themselves. When teachers assume these roles, they will exercise values relevant to the roles. The se values are the focus of discussion in this paper because it is believed that with the values practised by the teachers, they will automatically carry out the roles of teacher leaders and with the roles, they will definitely perform in their job as teachers.

Villiers and Pretorius (2012) in their research, A Changing Leadership Paradigm: SouthAfrican Educators' Perceptions of the Dimensions of a Healthy School Culture for Teacher Leadership, state their finding that four values out of seven being tested of teacher leadership are in existence in 283 educators from the Cape Province in South Africa. One of them is developmentally focused which shows that the teachers are interested to gain new knowledge and skills in teaching. They also have the spirit of mutual respect and caring towards each other which leads to teacher recognition of contributions made by colleagues. Teachers with leadership are also proactive and show they have autonomy in making improvements and innovations. Finally, teacher leaders have the feelings that they are respected by many such as parents, students and administrators. The research concludes that these values will guarantee teacher performance and improve school achievement (Villiers \& Pretorius, 2012). While the Center for Comprehensive School Reform and Improvement in its article Teacher Leaders: The Backbone of Sustained Improvement published in Newsletter (2005), is in agreement with the concept of the teacher leaders, which has identified five values that teacher leaders demonstrate. First is the collaborative attitude that teacher leaders portray. They are always discussing or facilitating meetings with colleagues in order to produce better teacher performance. Second, they profoundly participate in school decisions. Participating means these teacher leaders provide agenda items when issues about teaching instructions or teaching assessment or other teaching related issues are discussed. The third is teacher leaders would demonstrate expertise and are willing to share their knowledge. They are open to constructive criticism in order to improve their performance. Fourth, educators who have teacher leadership values in them would frequently perform self-reflection regarding their job and performance. This can be executed by means of study groups or professional learning communities for that matter. Finally, teacher leaders are said to become socially conscious about the complex issues surrounding the world of teaching namely culture, power, race and others. In conclusion, teachers with these values of teacher leadership are said to be the backbone of sustained school improvement when the teacher perform (Center for Comprehensive School Reform and Improvement, 2005). 
In the book entitled The Power of Teacher Leaders (2015), ten items have been acknowledged as the roles of teacher leaders. They act as professional developers. They also function as mentors to other teachers. In special education, teacher leaders are expected to act as servant leaders to special students. They need to portray themselves as promoting curriculum reform. Teacher leaders are expected to be in the capacity of school reformers. They are actively involved in providing strong first-year teacher preparation programme besides being team players in the educational institutions. When they declare themselves as part of the National BoardCertified Teachers, they are definitely playing the role of teacher leaders in order to extend the impact teacher leaders would have on other teachers. They are teacher leaders internationally when they go global. They are also expected to be cooperative leaders. These aforesaid roles have been accepted as the guidelines for teachers who want to practise teacher leadership which leads to effective teacher performance (Bond, 2015).

Talking about developing high quality teacher leadership, Jay Helbert (2015) has shared several attributes associated with teacher leadership. The attributes are the values that are illustrated by the teacher leaders. One with teacher leadership values will show ability to develop a plan or can be considered as a strategic thinker. Teacher leaders also have the ability to obey rules, follow instructions and adapt the mselves to meet the needs of the organizations so as to make reflection from time to time. They also possess the ability to motivate and influence other teachers. Other than that, they are team players because they involve and include others when discussing plans for school improvement and teacher performance. Teacher leaders act as mentors or coaches or advisors to other teachers when necessary. Helbert (2015) continues with the next attribute of teacher leaders being systems thinkers whereby they align problems and solutions to see the whole picture of the organization. In other words, they share the responsibility of sustaining the school improvement. Teacher leaders also develop others. This is to say they are not selfish to share with others. Finally, Helbert (2015) describes teacher leaders as researchers who would continuously improve themselves and others as well.

Azhar Harun, Ramli Basri, Zaidatol Akmaliah Lope Pehei and Soaib Asimiran (2016) have conducted a research to identify whether teacher leadership is in existence or not among the teachers of secondary schools in the east zone of Peninsular Malaysia. They found that the practice of teacher leadership is eminent among the teachers of the designated schools. The teachers show the characteristics of teacher leadership in performing their everyday work whereby these characteristics fall into the seven dimensions of teacher leaders by Katzenmeyer and Moller (2001). By portraying these characteristics, the teachers are actually carrying out their roles as teacher leaders. Based on the research by Azhar Harun et. al. (2016), the dimensions of teacher leaders, according to the level of intensity they are portrayed, are the positive environment, autonomy, open communication, collegiality, developmental focus, recognition and participation. This is to say that teachers who are leaders would seek to make their working environment a positive one. The existence of a positive environment would then lead to situations where teachers feel that they are respected and viewed as educational professionals and thus earned the respect of schools' community (Davignon, 2016). The value of autonomy brings the teacher leaders to a level where they take the initiatives to be a part of the decision makers in anything related to the future of the school (Davignon, 2016). Open communication is a good value being practised due to the fact that these teacher leaders interact with each other candidly which results in smooth problem-solving situations (Davignon, 2016). Teacher leaders collaborate in increasing their performance which is termed as collegiality and this has been a valuable role of teacher leaders (Davignon, 2016). Azhar Harun et. al. (2016) also find that teachers who assume themselves as leaders would focus on developing themselves. They engage themselves in learning sessions as well as encourage others to be in the same boat (Davignon, 2016). Another value of teacher leaders is the sense of recognition. Their work is recognized and vice versa. Finally, teacher leaders are said to be participative, which means they are actively involved in school's programmes and anything that has the needs for decision-making (Davignon, 2016).

Nonetheless, there are some teachers who refuse to accept the roles as teacher leaders (Muncey \& Conley, 1999). Some principals do not involve their teachers in decision making and do not encourage collaboration (Fon, 2016). There are even some negative perceptions of teacher leaders by the novice teachers (Nolan $\&$ Palazzolo, 2011). All these come into view due to several barriers obstructing teachers from executing their roles as teacher leaders such as lack of time, poor relationship with peers and/or administration, climate and structural factor and personal characteristics (Wenner \& Campbell, 2016). It can be deduced that these findings show 
refusal towards practising teacher leadership. Thus, this research intends to explore the values of teacher leadership that matter in making teachers perform better.

\section{Methodology}

The purpose of this paperwork is to explore the dimensions of teacher leadership which are important to teachers and could affect their performance. It is constructed using the Cross-Sectional Design based on the questionnaires distributed to the respondents (Zainudin Awang, 2012). The samples selected for this project paper are from the population of teachers of Mara Junior Science Colleges in the state of Kelantan, Malaysia in the amount of 130 (Krejcie \& Morgan, 1970). The instrument used to identify the dimensions or values of teacher leadership is a standard instrument which is the Teacher Leadership Self-Assessment (TLSA) by Katzenmeyer and Moller (2009). This instrument is widely used by researchers to observe the level of teacher leadership among the teachers (Davignon, 2016; Cheng \& Szeto, 2016; Fon, 2016). This questionnaire has been the choice of instrument due to the fact that it is simple, it has a good reliability and validity value and the questions are easily understood bringing about worldwide usage. Other studies related to teacher leadership utilizing this instrument are implemented in Philippine, Hong Kong, South Africa and The United States (Villier \& Pretorius, 2012; Cheng \& Szeto, 2016; Fon, 2016; Oracion, 2014).

TLSA consists of seven dimensions namely 1) self-awareness which refers to the teacher has a clear picture of self in terms of behaviours, strengths, philosophy and values; 2) leading change which refers to teacher applies effective strategies to facilitate positive improvement; 3 ) communication when the teacher shows effective listening, oral communication, presentation skills and expression in written communication; 4) diversity which means teacher demonstrates respect for and responds to differences in perspectives; 5 ) instructional proficiency and leadership referring to teacher possesses and uses professional knowledge and skills in providing the most effective learning opportunities for students and adults; 6) continuous improvement when teacher demonstrates commitment to reaching higher standards and readiness to take action to improve; and 7) self-organization referring to teacher establishes course of action and implements plans to accomplish results. After gaining the permission to use from Marilyn Katzenmeyer, the instrument had undergone the translation and adaptation process into Malay Language in order for it to be customized for Malaysian teachers ending up from 47 items from the original instrument of 42 items.

Measure of skewness was performed, as in Table 1, to determine that the sample data had been drawn from a normally distributed population and the skewness ranged from -1.199 to 0.184 .

Table 1. Measure of skewness

\begin{tabular}{|c|c|c|c|}
\hline ITEMS & SKEWNESS & ITEMS & SKEWNESS \\
\hline TL1 & -.491 & TL25 & -.004 \\
\hline TL2 & -1.178 & TL26 & -.307 \\
\hline TL3 & -.523 & TL27 & -.377 \\
\hline TL4 & -.470 & TL28 & -.203 \\
\hline TL5 & .184 & TL29 & -.219 \\
\hline TL6 & -.810 & TL30 & -.748 \\
\hline TL7 & -1.158 & TL31 & .018 \\
\hline TL8 & -.079 & TL32 & -.464 \\
\hline TL9 & -.409 & TL33 & -.171 \\
\hline
\end{tabular}




\begin{tabular}{|c|c|c|c|}
\hline TL10 & -.401 & TL34 & -.141 \\
\hline TL11 & -.420 & TL35 & -.455 \\
\hline TL12 & -.153 & TL36 & -.074 \\
\hline TL13 & -.522 & TL37 & -.111 \\
\hline TL14 & -.272 & TL38 & -.104 \\
\hline TL15 & -.269 & TL39 & -.371 \\
\hline TL16 & -.543 & TL40 & -.572 \\
\hline TL17 & -.265 & TL41 & -.204 \\
\hline TL18 & -.241 & TL42 & -.540 \\
\hline TL19 & -.436 & TL43 & -.207 \\
\hline TL20 & -1.199 & TL44 & -.689 \\
\hline TL21 & -.219 & TL45 & -.150 \\
\hline TL22 & -.143 & TL46 & -.152 \\
\hline TL23 & -.309 & TL47 & -.723 \\
\hline TL24 & -.487 & & \\
\hline & & & \\
\hline & & & \\
\hline
\end{tabular}

Before the Exploratory Factor Analysis was performed, the KMO Test and Bartlett's Test were implemented. Based on Table 2, the KMO reading is 0.81 while the Bartlett's Test of Sphericity showing a significant value of 0.000 which means that the data were suited for factor analysis to be performed.

Table 2. KMO and Bartlett's Test for Teacher Leadership

\begin{tabular}{|l|c|c|}
\hline \multicolumn{2}{|c|}{ Kaiser-Meyer-Olkin Measure of Sampling Adequacy. } & .81 \\
\hline Bartlett's Test of Sphericity & Approx. Chi-Square & 3426.585 \\
\cline { 2 - 3 } & Df & 1081 \\
\cline { 2 - 3 } & Sig. & .000 \\
\hline
\end{tabular}

Then the reduction process was carried out. Items with factor loading of above 0.5 would be the 'cleanest' items (Costello \& Osborne, 2005). Table 3 shows the factor loading for items of teacher leadership which have been reduced to 34 items under four dimensions.

Table 3. The Rotated Component Matrix for Teacher Leadership

\begin{tabular}{|l|c|c|c|c|}
\hline & Dimension 1 & Dimension 2 & Dimension 3 & Dimension 4 \\
\hline
\end{tabular}




\begin{tabular}{|c|c|c|c|c|}
\hline TL1 & 0.694 & & & \\
\hline TL2 & 0.734 & & & \\
\hline TL7 & 0.502 & & & \\
\hline TL9 & 0.521 & & & \\
\hline TL10 & & 0.590 & & \\
\hline TL11 & & 0.533 & & \\
\hline TL12 & & 0.598 & & \\
\hline TL14 & & 0.556 & & \\
\hline TL15 & & 0.669 & & \\
\hline TL17 & & 0.671 & & \\
\hline TL18 & & 0.645 & & \\
\hline TL19 & & 0.540 & & \\
\hline TL13 & & & 0.579 & \\
\hline TL23 & & & 0.652 & \\
\hline TL25 & & & 0.578 & \\
\hline TL26 & & & 0.591 & \\
\hline TL28 & & & 0.617 & \\
\hline TL30 & & & 0.611 & \\
\hline TL33 & & & 0.570 & \\
\hline TL34 & & & 0.642 & \\
\hline TL35 & & & 0.652 & \\
\hline TL36 & & & 0.539 & \\
\hline TL20 & & & & 0.545 \\
\hline TL31 & & & & 0.656 \\
\hline TL37 & & & & 0.686 \\
\hline TL38 & & & & 0.668 \\
\hline TL39 & & & & 0.779 \\
\hline TL40 & & & & 0.754 \\
\hline TL41 & & & & 0.660 \\
\hline
\end{tabular}




\begin{tabular}{|c|l|l|l|c|}
\hline TL42 & & & & 0.671 \\
\hline TL43 & & & & 0.520 \\
\hline TL44 & & & & 0.676 \\
\hline TL45 & & & & 0.712 \\
\hline TL46 & & & & 0.658 \\
\hline
\end{tabular}

In order to further confirm the finding, Confirmatory Factor Analysis (CFA) was performed using AMOS 18.0. Figure 1.0 shows the CFA measurement model for teacher leadership. Based on the four dimensions of teacher leadership, items with factor loading of 0.6 and below were reduced producing the last measurement model consisting of 3 items to measure self-awareness, 6 items to measure communication and change, 9 items to measure diversity and instructional proficiency and 10 items to measure organized and continuous improvement.

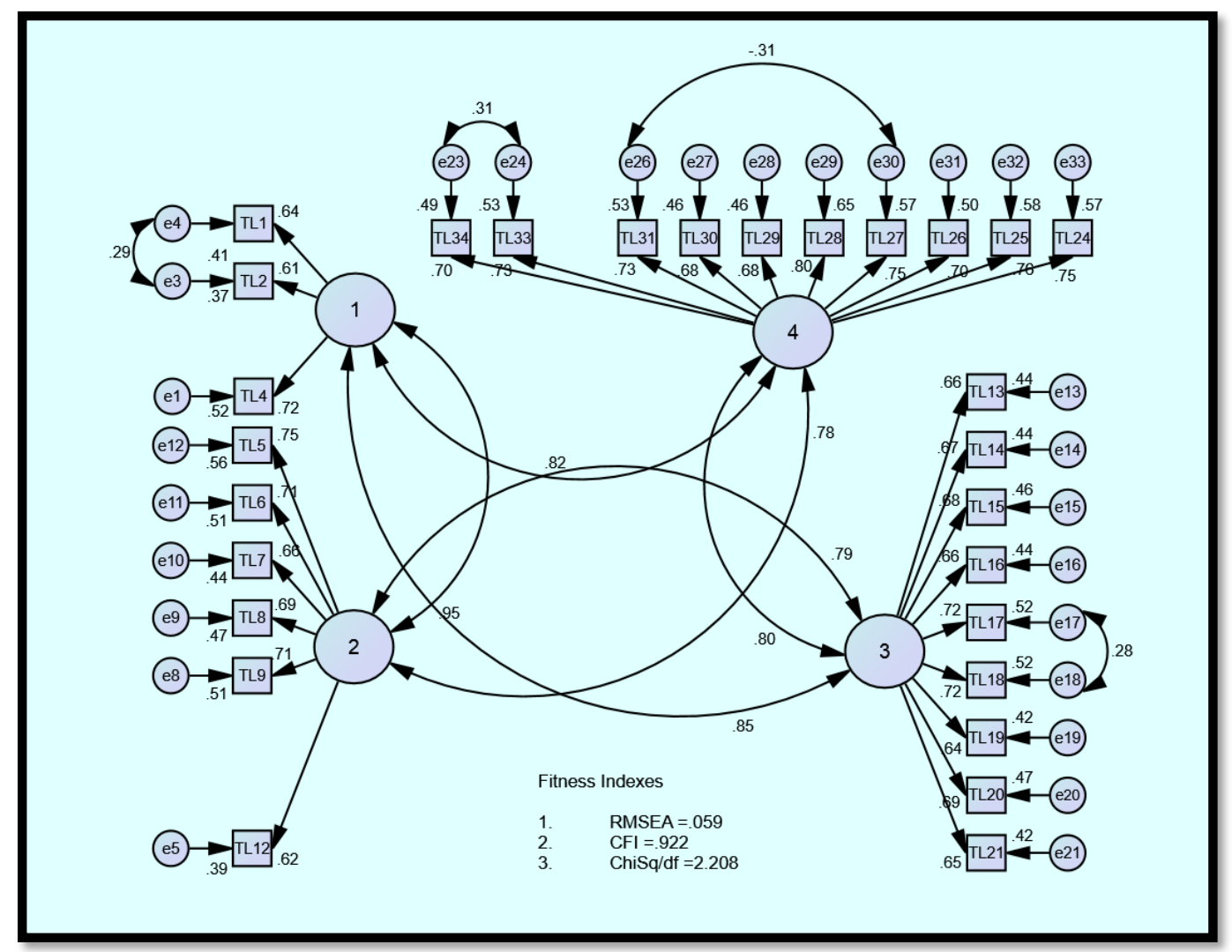

Figure 1: Measurement Model of Teacher Leadership

Figure 1.1 is self-awareness, 2 is communication and change, 3 is diversity and instructional proficiency and 4 is organized and continuous improvement.

Table 4 shows the summary of discrimination of index validity. In Structural Equation Modelling, there are several fitness indices which describe the suitability of model obtained from collected data such as chi-square relationship (CMINDF: the chi-square/degree of freedom, Comparative Fit Index (CFI), Goodness of Fit Index (GFI) and Root Mean Square of Error Approximation (RMSEA). Holmes-Smith, Coote, and Cunningham (2005) 
and Zainudin Awang (2012) support the application of fitness indices to build a fit model. The value that is suggested for chi-square degree of freedom is $<3.0$ (Zainudin Awang, 2015) and this model has a chisq/df of 2.208. The value of CFI is 0.922 this Incremental Fit Category has satisfied the required level since the value of $\mathrm{CFI}$ is $>0.90$. The value of RMSEA obtained is 0.059 . The Absolute Fit Category has achieved the required level since the value of RMSEA obtained is less than 0.08 as suggested by Browne and Cudeck (1993).

Table 4. Summary for the Assessment of Fitness Indexes

\begin{tabular}{|c|c|c|c|c|}
\hline Category & Fit statistics & Recommended & Obtain & Comment \\
\hline Absolute Fit & RMSEA & $<0.08$ & 0.059 & Achieved \\
\hline Incremental Fit & CFI & $>0.90$ & 0.922 & Satisfied \\
\hline Parsimonious Fit & Chisq/df & $<3.0$ & 2.208 & Achieved \\
\hline
\end{tabular}

Then, the reliability test was performed. Table 5 shows the values of reliability analysis for each dimension. The $\alpha$ value for self-awareness is 0.705 , communication and change are 0.839 , diversity and instructional improvement is 0.879 and organized and continuous improvement is 0.914 .

Table 5. Reliability Analysis of Instrument

\begin{tabular}{|c|r|c|}
\hline VARIABLE & DIMENSION & CRONBACH ALPHA \\
\hline \multirow{3}{*}{ Teacher Leadership } & Self-awareness & 0.705 \\
\cline { 2 - 2 } & Communication and change & 0.839 \\
\cline { 2 - 2 } & Diversity and instructional improvement & 0.879 \\
\cline { 2 - 2 } & Organized and continuous improvement & 0.914 \\
\cline { 2 - 2 } & & \\
\hline
\end{tabular}

\section{Result}

Based on the analysis performed, from seven dimensions of TLSA by Katzenmeyer and Moller (2009), there are four dimensions of teacher leadership which are relevant to the Malaysian setting. The first dimension, with three items related to self-awareness, is labelled as self-awareness. As for the second dimension, the items were a mixture of questionnaires from the dimensions of leading change and communication. With six items under this dimension, it is termed as communication \& change dimension. Several items from the dimension of diversity and some from the instructional proficiency and leadership dimension make the third dimension. Thus, it is labelled as the dimension of diversity and instructional proficiency. Finally, having ten items from continuous improvement and self-organization dimensions, the last dimension is termed as organized and continuous improvement.

\section{Discussion and Conclusion}

In Malaysian setting, there are four dimensions relevant to teacher leadership and these dimensions represent the significant values that teachers as leaders need to have. The first dimension is self-awareness. This refers to a teacher having a definite and concrete picture of him or herself as an educator. Being able to identify 
personal strengths and values in order to function as effective teachers is a proven value for teachers in acting out the role of teacher leaders (Katzenmeyer \& Moller, 2009). With the strengths and values, come the philosophy and proper behaviours mandatory for effective teacher leaders. Self-awareness will also bring about understanding of how the teacher's values and emotions regulate his or her behaviour, judgement and selfbelief (Helbert, 2015). This, in the end, will help teachers evaluate how they are doing as leaders and which areas they need to improve. Thus, the value of self-awareness is definitely an imperative and necessary value for teachers to be effective in their performance.

The second dimension involves communication and change. This dimension stresses on the skill of communication that teachers could not do without. The finding of this project paper has proven that teachers, in their effort to perform better will have to improve their communicational skills so that when they listen, they will listen effectively, when they converse, they will relate effectively, when they present, their presentation is sound, and when they put words on paper, the effect is dramatic. Teachers need this to lead change in educational organizations. Since change is the only constant thing in this world, teachers are advised to equip themselves with effective strategies in order to facilitate positive change.

Diversity and instructional proficiency is the third dimension identified by this project paper. Teachers need to be diverse. They need to demonstrate respect for differences among people specifically their students and colleagues. With that in mind, they could respond to differences in a more productive and compelling manner. Instructional proficiency signifies teachers having professional knowledge and skills in delivering the most productive learning sessions for students.

Finally, the result of the study reveals the last dimension for teacher leadership which is organized and continuous improvement. This finding proves that teachers need to be organized by enacting course of actions and executing the plan in order to achieve the desired results. This has to be an on-going process with teachers showing a high level of commitment to improve their performance as well as the student performance.

In conclusion, this project paper is executed with the aim of identifying the dimensions of teacher leadership which have high validity and reliability values. These dimensions could be illustrated as values which are relevant and important to teachers specifically in Malaysia. This finding can be used by other researchers in building a sound teacher leadership model in order to produce more teacher leaders as well as designing programmes to develop teacher leadership skills based on these dimensions.

\section{Acknowledgments}

Our thanks to everyone who has contributed in making the findings of this project paper a reality.

\section{References}

1. Azhar Harun, Ramli Basri, Zaidatol Akmaliah Lope Pehei \& Soaib Asimiran. (2016). Amalan kepimpinan guru di sekolah menengah zon timur Semenanjung Malaysia. Jurnal Kepimpinan Pendidikan, 3(4), 1-24.

2. Berry, B., Daughtrey, A. \& Wieder, A. (2010). Teacher leadership: Leading the way to effective teaching and learning. Center for Teaching Quality. Retrieved from https://www.teachingquality.org/content/teacher-leadership-leading-way-effective-teaching-andlearning

3. Bond, Nathan. (Ed.). (2015). The power of teacher leaders. Indiana: Kappa Delta Pi.

4. Browne, M.W. \& Cudeck, R. (1993). Alternative ways of assessing model fit. In Bollen, K.A. \& Long, J.S. [Eds.] Testing structural equation models. Newbury Park, CA: Sage, 136-162.

5. Cheng, A. Y. N. \& Szeto, E. (2016). Teacher leadership development and principal facilitation: Novice teachers' perspectives. Teaching and Teacher Education, 58, 140-148. 
6. Costello, Anna B. \& Osborne, Jason. (2005). Best practices in exploratory factor analysis: four recommendations for getting the most from your analysis. Practical Assessment Research \& Evaluation, 10(7).

7. Davignon, M.M. (2016). New teachers' perceptions of teacher leaders: Trust in the educational setting (Doctoral dissertation). Retrieved from https://academicarchive.snhu.edu/handle/10474/2634

8. Fon, T. P. (2016). A study of teachers' perceptions of involvement in decision making within secondary schools in Cameroon. Journal of Educational and Social Research, 6(2), 165-175.

9. Gronn, Peter. (2000). Distributed properties: A new architecture for leadership. Educational Management Administration Leadership, 28(3), 317-338.

10. Helbert, J. (2015). Developing high quality teacher leadership in a primary school (Paper submitted to the Scottish College for Educational Leadership Fellowship Programes). Retrieved from http://www.scelscotland.org.uk/wp-content/uploads/2016/07/Developing-High-Quality-TeacherLeadership-in-a-Primary-school

11. Henman, Linda. (2017). Leadership: Theories and controversies. Retrieved from www.henmanperformancegroup.com

12. Holmes-Smith, P., Coote, L., \& Cunningham, R. E. (2005). Structural Equation Modelling: From the fundamentals to advanced topics. Melbourne, Australia: School Research, Evaluation and Measurement Services.

13. Katzenmeyer, M. \& Moller, G. (2001). Awakening the sleeping giant: Helping teachers develop as leaders. Newbury Park, CA: Corwin Press.

14. Katzenmeyer, M. \& Moller, G. (2009). Awakening the sleeping giant: Helping teachers develop as leaders ( ${ }^{\text {rd }}$ ed.). Thousand Oaks, CA: Corwin Press.

15. Kementerian Pendidikan Malaysia. (2013). Pelan Pembangunan Pendidikan Malaysia (PPPM) 20132025. Putrajaya: Kementerian Pendidikan Malaysia.

16. Krejcie, R. V. \& Morgan, D. W. (1970). Determining sample size research activities. Educational and Psychological Measurement, 30, 607-610.

17. Muijs, D. \& Harris, A. (2003). Teacher leadership-Improvement through empowerment? Educational Management \& Administration, 31(4), 437-448.

18. Mulford, B. (2003, April). School leaders: Changing roles and impact on teacher and school effectiveness. Paper commissioned by the Education and Training Policy Division, OECD, University of Tasmania.

19. Muncey, D. E. \& Conley, S. (1999). Teacher compensation and teacher teaming: Sketching the terrain. Journal of Personnel Evaluation in Education. 12(4), 365-385.

20. Norashikin Abu Bakar, Ramli Basri \& Fooi, F. S. (2015). Hubungan kepimpinan Guru dengan pencapaian akademik pelajar. International Journal of Education and Training, 1(2), 1-11.

21. Nolan, B. \& Palazzolo, L. (2011). New teacher perceptions of "teacher leader" movement. NASSP Bulletin, 95(4), 302-318.

22. Oracion, C. C. (2014). Teacher leadership in public schools in the Philippines (Doctoral dissertation, University of London). Retrieved from http://eprints.ioe.ac.uk/21652/1/Thesis-final.pdf 
23. Sugg, S. A. (2013). The relationship between teacher leadership and student achievement (Doctoral dissertation, Eastern Kentucky University). Retrieved from http://encompass.eku.edu/etd

24. Terry, P. M. (2017). Empowering teachers as leaders. National Forum Journals. Retrieved from http://www.nationalforum.com/Electronic\%20Journal\%20Volumes/Terry,\%20paul\%20M.\%20Empoweri $\mathrm{ng}$

25. Villiers, E., Pretorius, S. G. (2012). A changing leadership paradigm: South African Educators' perceptions of the dimensions of a healthy school culture for teacher leadership. Journal of Social Science, 32(2), 205-219.

26. Wenner, J. A. \& Campbell, T. (2016). The theoretical and empirical basis of teacher leadership: A review of the literature. Review of Educational Research, $X X(X), 1-38$.

27. Wills, A. (2015). A case study of teacher leadership at an elementary school (Doctoral dissertation). Retrieved from http://digitalcommons.sacredheart.edu/edl

28. York-Barr, J. \& Duke, K. (2004). What do we know about teacher leadership? Findings from two decades of scholarship. Review of Educational Research, 74(3), 255-316.

29. Zainudin Awang. (2012). Research methodology and data analysis ( $2^{\text {nd }}$ ed.). Shah Alam: UiTm Press.

30. Zainudin Awang. (2012). Structural Equation Modeling Using Amos Graphic. Universiti Teknologi Mara.

\section{About Wan Suhaila Wan Yaacob}

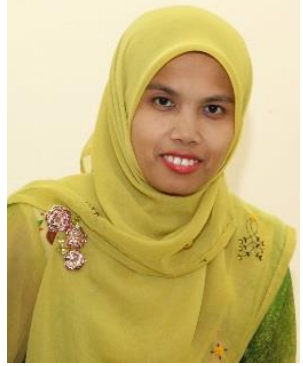

Wan Suhaila Wan Yaacob is the Deputy Principal of Academic Excellence in MARA Junior Science College Pasir Tumboh, Kelantan, Malaysia. Currently doing her PhD in Education at Universiti Utara Malaysia. Published articles and presented papers at Seminars. An Administrator by day and a reader by night. 